\title{
ANALISIS PERSAINGAN PENDIDIKAN TINGGI DI BATAM DARI PERSPEKTIF POLITEKNIK BATAM
}

\author{
Dwi Kartikasari, Sinarti, Rahmat Hidayat, dan Irsutami \\ Politeknik Negeri Batam \\ email: dwi@polibatam.ac.id
}

\begin{abstract}
Abstrak: Perguruan tinggi vokasi dihadapkan pada tuntutan untuk meningkatkan kontribusi dan relevansinya dalam peningkatan daya saing kawasan industri di Batam dan sekitarnya melalui dukungan sumber daya manusia. Selain itu, perguruan tinggi vokasi di Batam juga dihadapkan pada tantangan untuk menemukan formula yang tepat untuk ditawarkan kepada masyarakat. Oleh sebab itu, penelitian ini bertujuan untuk menganalisis persaingan yang dihadapi oleh perguruan tinggi di Batam dan kemudian secara khusus memetakan posisi Politeknik Batam di tengah perguruan tinggi lainnya. Data dianalisis dengan teknik dskriptif kualitatif dan kuantitatif yang berupa statistik deskriptif. Berdasarkan hasil survei kepada 1970 lulusan SMA dan yang sederajat dan studi dokumen kliping koran selama satu tahun, penelitian ini mengindikasikan ketatnya tingkat persaingan pendidikan tinggi di Batam dilihat dari lima kekuatan Porter. Lebih lanjut, hasil penelitian menunjukkan bahwa pendidikan tinggi vokasi di Batam berada pada kondisi yang lemah dengan kompetitor yang lebih unggul.
\end{abstract}

Kata Kunci: kompetisi, positioning, pendidikan vokasi

\section{AN ANALYSIS OF HIGHER EDUCATION COMPETITION IN BATAM IN THE PERSPECTIVE OF BATAM POLYTECHNIC}

\begin{abstract}
Vocational colleges were faced with demands to increase their contribution and relevance in improving the competitiveness of the industrial area in Batam and its surrounding areas by means of developing the quality of the human resources. In addition, vocational colleges in Batam were also faced with the challenge of finding the right service to be offered to the local community. Therefore, this study aimed to analyze the competition faced by vocational colleges and then mapped out the position of Batam Polytechnic among other higher education. The data were analyzed using the qualitative and quantitative descriptive analyses. Based on a survey to 1970 senior high school students and a documentation study on newspapers in one year, this study indicated the high level of competition among higher education in Batam using Porter's five strength analysis. Furthermore, the research showed that the position of the vocational college was in the "weak position" with superior competitors.
\end{abstract}

Keywords: competition, positioning, vocational college

\section{PENDAHULUAN}

Proses link and match antara penyedia tenaga kerja, yaitu sekolah dan perguruan tinggi (PT) dengan industri dapat tercipta apabila PT dapat menyediakan tenaga kerja yang terampil dan memiliki kompetensi yang sesuai dengan kebutuhan dunia kerja. Untuk itu, perguruan tinggi khususnya vokasi, diharapkan dapat berperan besar untuk menyediakan tenaga kerja terampil dan kompeten dalam upaya meningkatkan daya saing, khussnya di kawasan industri di Batam dan sekitarnya melalui dukungan sumber daya manusianya.

Di samping dukungan sumber daya ma- nusia, PT dapat juga berperan dalam mendukung infrastruktur yang dibutuhkan oleh industri di sekitarnya seperti penyediaan laboratoryum kalibrasi dan sertifikasi kualitas. PT juga dapat memengaruhi kondisi permintaan domestik di dalam kawasan, khususnya apabila PT adalah sasaran pelanggan bagi sejumlah industri misalnya industri pembuatan alat ajar dan multimedia. PT berpotensi besar memberikan kesempatan yang lebih banyak pada industri melalui riset yang inovatif.

Kesadaran pentingnya peran PT dalam meningkatkan daya saing kawasan telah mendorong berdirinya PT. Pada saat ini, terdapat 38 
PT di Provinsi Kepri; lebih dari 70 persen di antaranya berlokasi di Kota Batam. Sementara itu, jumlah penduduk yang terkonsentrasi di Batam tidak lebih dari 60 persen. Perbedaan persentase konsentrasi ini menunjukkan adanya persaingan yang ketat untuk memperebutkan calon mahasiswa lokal yang terbatas. Akibatnya, sangat memungkinkan sebuah PT tutup karena kekurangan mahasiswa. Sementara itu, Direktorat Jenderal Pendidikan Tinggi telah mensyaratkan bahwa PT harus memiliki minimal 30 mahasiswa per angkatan per program studi/jurusan (Rurit, 2008). Selama ini, masyarakat umumnya beranggapan bahwa PT yang notabene lembaga sosial, tidak perlu melakukan analisis pemasaran seperti yang biasa dilakukan oleh lembaga berorientasi laba(Widiyoko, 2012).

Padahal, persaingan pendidikan tinggi terjadi tidak hanya di tingkat lokal dan nasional, juga regional dan global yang mengharuskan daerahperbatasan seperti di Batam untuk mengevaluasi peta kompetisinya agar tetap beroperasi. Ketatnya persaingan, mendorong PT untuk menonjolkan identitasnya sebagai PT yang selaras dengan fakta dan kerangka kerja industri. Jika tidak, branding image akan menimbulkan boomerang effect karena hanya memberikan harapan palsu kepada pelanggannya.

Salah satu faktor yang dapat meningkatkan daya saing PT secara optimal adalah kualitas lulusannya. Dengan demikian, PT membutuhkan input mahasiswa yang berkualitas yang dapat memberikan tekanan yang lebih kuat kepada PT untuk memberikan pelayanan yang lebih baik (Porter, 1990). Kualitas mahasiswa bergantung pada kemampuan PT dalam menarik calon mahasiswa terbaik di daerahnya.

Perguruan tinggi membutuhkan rencana strategis pemasaran untuk menyasar kelompok pelanggan yang diinginkan sehingga dapat menarik calon mahasiswa terbaik. Peta psikologis perlu disusun sedemikian rupa sehingga setiap PT memperoleh mahasiswa sesuai dengan sasarannya (target market) masing-masing. Dengan demikian, PT akan lebih mudah menyesuaikan program kerjanya dengan kebutuhan kelompok pelanggan tertentu, dibandingkan jika pelanggan terlalu heterogen dan divergen.
Di samping itu, mahasiswa juga akan lebih mudah berinteraksi secara horizontal dengan komunitas yang "mirip" dengan kondisinya sehingga meningkatkan tingkat kepuasan dan retensi mahasiswa dan mengurangi persentase drop-out.

Penyusunan peta psikologis yang mudah diingat oleh kelompok pelanggan membutuhkan variabel-variabel yang paling signifikan dalam industri yang dimaksud untuk diletakkan dalam diagram. Contohnya, untuk sejumlah produk, variabel yang diusung adalah harga dan kualitas; untuk retail adalah lingkungan yang nyaman dan kelengkapan produk yang ditawarkan. Untuk PT, perlu diidentifikasi variabelvariabel yang paling signifikan diingat oleh calon mahasiswa, khususnya lulusan SMA/ SMK di Batam dan sekitarnya.

Berdasarkan data Dikti tahun 2014, jumlah mahasiswa aktif pada pendidikan tinggi vokasi, dari akademi dan politeknik, dalam mencetak tenaga kerja hanya sekitar 10 persen dari total mahasiswa yang terdaftar di perguruan tinggi besar di wilayah Kepri. Fakta ini menunjukkan bahwa kontribusi pendidikan tinggi vokasi di wilayah Kepri tergolong lebih rendah daripada perguruan tinggi lainnya. Padahal, dengan banyaknya industri di wilayah ini, masyarakat tentunya mengharapkan partisipasi yang sebesar-besarnya dari pendidikan tinggi vokasi dalam pembangunan sumber daya manusia.

Pendidikan tinggi di Batam dihadapkan pada tantangan untuk berkompetisi dengan industri dalam perebutan lulusan SMA dan yang sederajat. Pendidikan tinggi vokasi di Batam juga berkompetisi dengan PT lain, baik lokal maupun nasional, untuk menarik mahasiswa berkualitas. Kompetisi ini cukup ketat mengingat banyaknya kompetitor lokal untuk memperebutkan lulusan SMA sederajat yang terbatas.

Tantangan pendidikan tinggi di Batam dan sekitarnya semakin besar apalagi jika dihadapkan pada fakta bahwa mayoritas PT lokal tergolong masih muda: belasan tahun. Ibarat remaja, PT lokal masih dalam proses pencarian jati diri untuk menemukan bentuk yang sesuai untuk ditawarkan kepada masyarakat. 
Oleh sebab itu, penelitian ini berusaha untuk memberikan masukan kepada PT di Batam dan sekitarnya mengenai persaingan pendidikan tinggi sehingga kampus-kampus dapat me(re)posisikan kampusnya di tengah persaingan yang ketat. Eksplorasi positioning pendidikan tinggi tidak hanya bermanfaat bagi perguruan tinggi, namun juga bagi masyarakat sehingga masyarakat dapat memilih PT yang cocok dengan profilnya. Semakin kokohnya PT memosisikan dirinya di kancah dunia pendidikan di daerahnya, diharapkan PT mampu berkontribusi lebih besar dalam meningkatkan daya saing kawasan.

\section{METODE}

Penelitian ini menggunakan pendekatan penelitian sebagai berikut. (1) Survei lapangan, khususnya untuk mensurvei siswa sekolah menengah atas atau sederajat. (2) Riset dokumen lewat studi terhadap kliping surat kabar untuk mengetahui profil kompetitor, baik kompetitor langsung maupun penyedia jasa substitusi. Kebijakan yang ditetapkan untuk memastikan kualitas data adalah (1) kuisioner yang tidak diisi dengan lengkap, tidak diinput, data outlier tidak dipertimbangkan dalam analisis data; dan (2) iklan/artikel yang tidak menyebutkan kontak yang jelas tidak akan diinput.

Sampel penelitian ini adalah (1) sebanyak 1970 orang siswa SMA dan yang sederajat semua jurusan di wilayah Kepri yang akan lulus di tahun 2014; dan (2) sebanyak 1525 buah iklan lowongan kerja di koran terbesar di Batam dalam jangka waktu satu tahun, yaitu Oktober 2012 sampai September 2013. Data dianalisis dengan teknik dskriptif kualitatif dan kuantitatif yang berupa statistik deskriptif.

\section{HASIL DAN PEMBAHASAN}

\section{Ancaman Persaingan dari Pendatang Baru}

Pada tahun 2000, Politeknik Batam didirikan bersamaan dengan tiga PT lainnya. Pada tahun 2010, Politeknik Batam berubah status dari swasta menjadi negeri dan berubah nama menjadi Politeknik Negeri Batam (Polibatam). Polibatam menjadi PTN pertama di Kepri. Setelah itu, dua PTN lainnya berdiri. Di sam- ping PTN, perguruan tinggi swasta juga terus bermunculan seperti dapat dilihat pada Gambar 1. Saat ini jumlah PT lokal adalah 38 dan akan terus bertambah.

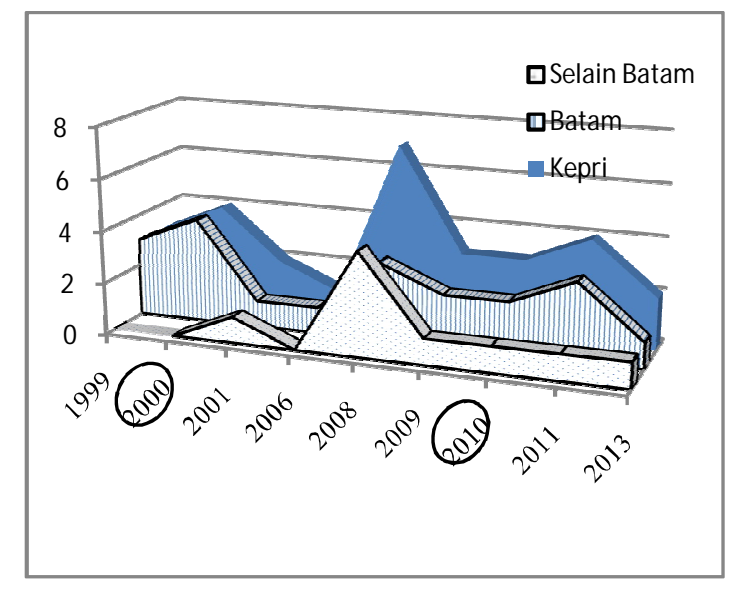

\section{Gambar 1. Pendirian Perguruan Tinggi Lokal 1993-2013}

Pendirian PT diatur oleh Dirjen Dikti. Di era informasi saat ini, secara teknis, mekanisme pendaftaran PT baru menjadi lebih mudah dan lebih transparan berkat sistem online sehingga PTbaru hanya membutuhkan waktu yang relatif singkat untuk memasuki persaingan pendidikan tinggi di Batam. Meskipun Dikti menetapkan syarat-syarat pendirian PT, secara prinsip Dikti tidak menghambat pendirian PT baru. Justru pendirian PT, utamanya vokasi dan sains saat ini memperoleh preferensi.

Sejak September 2012, pemerintah menghentikan sementara (moratorium) pendirian PT baru termasuk pembukaan program studi baru (Napitupulu, 2012). Akibatnya, jumlah PT baru di Kepri pada tahun 2013 berkurang dari tahun-tahun sebelumnya. Kebijakan ini ditetapkan untuk merespons Undang-Undang Pendidikan Tinggi (UU PT) yang memuat berbagai ketentuan baru tentang pendirian dan perubahan bentuk PT, pembukaan program studi baru, dan mengamanatkan penguatan pendidikan vokasi.

Namun, pengecualian terhadap kebijakan moratorium ini dapat dilakukan jika pemerintah memandang perlu untuk diselenggarakan program-program studi tertentu pada wilayah- wilayah tertentu karena kebutuhan negara. 
Syarat pendirian PT yang ditetapkan Dikti tergolong mudah, di antaranya adalah sebagai berikut.

- Yayasan sudah mendapatkan pengesahan dari Kementerian Hukum dan HAM RI dan tidak dalam konflik internal.

- Fotokopi Akta Pendirian Yayasan yang menyatakan menyelenggarakan Pendidikan Tinggi.

- Yayasan memiliki lahan untuk Akademi, Politeknik, dan Sekolah tinggi minimal $5.000 \mathrm{~m}^{2}$, Institut $8.000 \mathrm{~m}^{2}$ dan Universitas minimal $10.000 \mathrm{~m}^{2}$.

- Laporan keuangan periode terakhir untuk yayasan yang sudah berdiri lebih satu tahun. Fotokopi rekening koran tiga bulan terakhir untuk yayasan yang sudah berdiri kurang dari satu tahun.

- Melengkapi persyaratan pendirian PT, meliputi: (1) rencana induk pengembangan (RIP); (2) studi kelayakan; (3) sumber pembiayaan; (4) sarana dan prasarana; (5) penyelenggara PT; (6) akta notaris pendirian yayasan; (7) SK pengesahan/surat penyesuaian; (8) standar penjamin mutu internal;

(9) rancangan standar pendidikan.

Berdasarkan persyaratan tersebut, maka yayasan dapat mendirikan PT dalam tempo minimal tiga bulan sejak berdiri.

Biaya pendirian PT baru terdiri atas biaya gedung/lahan, fasilitas, biaya rekrut dan gaji minimal enam dosen dan jaminan. Biaya gedung dan lahan dapat diminimalisasi jika yayasan/pendiri memilih untuk menyewa gedung perkuliahan. Proses pendirian PT dan pembukaan prodi tidak dipungut biaya oleh Dirjen Dikti (2012). Selain biaya administrasi untuk memenuhi persyaratan di atas, untuk mendirikan PT, yayasan/pendiri harus menyiapkan biaya rekrut serta gaji minimal 6 dosen tetap per prodi. Untuk PT berbentuk akademi, Dikti mensyaratkan minimal satu program diploma. Yohanas Oemar (Inhu Makmur Raya, 2012) menyatakan bahwa untuk mendirikan sebuah universitas dibutuhkan biaya administrasi mencapai Rp 1,8 miliar. Bagi masyarakat Batam yang memiliki rata-rata penghasilan tergolong tinggi, peringkat lima dari 82 kota (BPS, 2014), dana minimal di atas dianggap terjangkau.

Pendatang baru dapat dibatasi jika saja ada paten atau specialist knowledge yang dimiliki oleh PT tertentu. Akan tetapi, dengan adanya aturan Dikti yang ketat mengenai kurikulum dan Standar Kerangka Kualifikasi Nasional Indonesia (SKKNI), profil lulusan sebuah prodi, misalnya akuntansi, relatif seragam. Selain itu, specialist knowledge berkurang perannya mengingat pelatihan-pelatihan tersedia secara luas. Teknologi secara umum kurang terproteksi, pertama disebabkan oleh minimnya teknologi paten yang dihasilkan, bahkan oleh PT lama sekalipun, dan kedua, karena sistem proteksi yang masih lemah.

Aturan mengenai rasio dosen terhadap mahasiswa juga menyebabkan economies of scale kurang relevan karena peningkatan jumlah pelanggan yang dilayani tidak serta merta mengurangi biaya penyelenggaraan kuliah, khususnya biaya upah tenaga pendidik. Dengan adanya standarisasi mutu dan sistem akreditasi, dalam waktu yang relatif singkat, PT baru dapat segera menyesuaikan diri untuk bersaing dengan PT lama.

Oleh sebab itu, tekanan persaingan pendidikan tinggi di wilayah Batam yang ditimbulkan oleh pendatang baru selama ini tergolong tinggi. Akan tetapi, saat ini, tekanan mulai agak melemah disebabkan kebijakan moratorium. Moratorium ditetapkan sebab pemerintah merasa perlu menata PT yang ada supaya kualitasnya meningkat serta untuk mengatur keberadaan PT berdasarkan lokasi dan juga kebutuhan untuk memperbanyak pendidikan vokasi di jenjang perguruan tinggi(Suara Merdeka, 2011). Namun, tekanan dari pendatang baru tidak dengan serta merta hilang karena di wilayah perbatasan yang strategis seperti di Batam dan Kepri, kebijakan moratorium ini sangat mungkin memperoleh pengecualian. Selain itu, setelah tahun 2014 ketika kebijakan moratorium dicabut, tekanan pendatang baru dapat kembali menguat. 
Ancaman Persaingan dari Penyedia Jasa Substitusi

Beberapa jasa substitusi pendidikan tinggi di Batam di antaranya adalah: (1) jasa substitusi yang menggantikan fungsi jasa pendidikan tinggi, misalnya pendidikan tinggi dari luar daerah; (2) jasa substitusi yang menggantikan sebagian fungsi jasa pendidikan tinggi, yaitu sertifikasi kompetensi dan pendidikan nonformal; (3) jasa substitusi yang terjadi karena pelanggan harus memilih, contohnya industri, sebab lulusan SMA harus memilih antara melanjutkan pendidikan atau bekerja di industri.

Tekanan substitusi pendidikan tinggi dari luar Batam termasuk sangat kuat khususnya dari luar Kepri. Hal ini sesuai dengan hasil survei yang ditunjukkan pada Gambar 2.

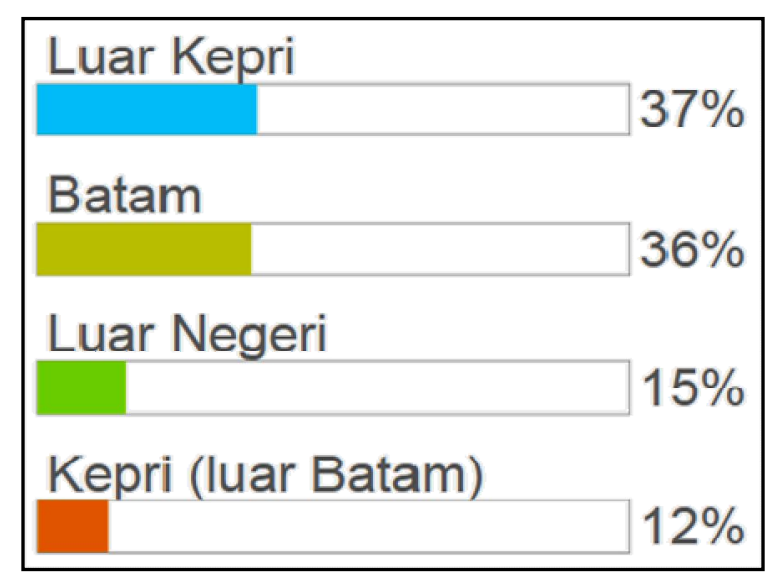

Gambar 2. Preferensi Lulusan SMA Sederajat Mengenai Lokasi Melanjutkan Pendidikan Tinggi

Kebanyakan calon mahasiswa yang merupakan pelanggan eksternal (Priamiani \& Ariani, 2005:178) bagi pendidikan tinggi di Batam berharap dapat melanjutkan pendidikan di luar provinsi Kepri. Jumlah calon pelanggan yang ingin melanjutkan ke luar Batam bahkan lebih banyak daripada yang ingin melanjutkan di Batam. Grafik ini menunjukkan bahwa daya tarik PT luar daerah lebih kuat dibandingkan PT lokal sehingga tekanan persaingan dari luar daerah terhadap pendidikan tinggi di Batam sangat kuat.

Adapun tekanan persaingan dari jasa substitusi seperti pendidikan nonformal dan sertifikasi kompetensi tergolong moderat sebab jumlah penyedia jasa subsitusi tidak terlalu banyak; hanya dua atau tiga lembaga yang tergolong kuat, sebagai pemain lama yang eksistensinya sudah teruji. Organisasi selain pendidikan tinggi yang menyediakan pendidikan nonformal dan sertifikasi seperti ditunjukkan pada Tabel 1.

Daftar itu menunjukkan bahwa hanya Ikbal-M-Yos, BLK, dan BSDC yang performansinya cukup konsisten. Ikbal-M-Yos merupakan lembaga kursus yang tertua dan memberikan tekanan persaingan yang paling kuat, khususnya untuk training welding Polibatam, namun tidak memberikan tekanan persaingan langsung kepada prodi-prodi. Balai Latihan Kerja (BLK) memunyai program training yang kuat hingga tahun 2009. Namun, sejak pengelolanya (Yayasan Karya Bangsa) dibubarkan, perannya berkurang. Batam Skills Development Center (BSDC) menawarkan bermacam-macam kompetensi seperti yang ditawarkan oleh Polibatam, namun target market-nya berbeda; BSDC difokuskan untuk memperkuat kompetensi lulusan SMK.

Sebagian besar penyedia jasa substitusi sama-sama menyediakan pendidikan yang mampu memberikan kompetensi yang dibutuhkan untuk industri, namun tidak memberikan ijazah dan gelar akademik. Tekanan dari jasa substitusi di atas tidak sebesar tekanan dari kompetitor langsung, namun perlu tetap diwaspadai oleh pendidikan tinggi sebab pendidikan tinggi biasanya menargetkan pendapatan ekstra dari penyelenggaraan pendidikan nonformal dan sertifikasi. Jasa substitusi berupa pendidikan nonformal dan sertifikasi mampu menekan harga yang ditetapkan PT untuk memperoleh sertifikat dari organisasinya.

Tekanan jasa substitusi dari industri yang menyebabkan pelanggan harus memilih antara kuliah dan bekerja tergolong normal. Berdasarkan survei dapat diketahui bahwa sebagian besar (83 persen) calon pelanggan berharap dapat melanjutkan pendidikan setelah lulus SMA. 
Tabel 1. Penyedia Jasa Substitusi Pendidikan Tinggi

\begin{tabular}{|c|c|c|}
\hline No. & Kursus dan Sertifikasi & Nama Lembaga \\
\hline 1. & $\begin{array}{l}\text { Teknik maritim, migas dan } \\
\text { Pelatihan ahli K3 Umum }\end{array}$ & $\begin{array}{l}\text { 1) Ikbal-M-Yos, 2) Offshore Technology Institute (OTI)/ PT Kiat Global } \\
\text { Batam Sukses, 3) Australian Skills Training (AST), 4) PT Lekom Maras, 5) } \\
\text { DiGiSi } \\
\text { PT Tachi Jino, 6) Balai Latihan Kerja (BLK) }\end{array}$ \\
\hline 2. & $\begin{array}{l}\text { Pelatihan bahasa Inggris dan } \\
\text { bahasa asing }\end{array}$ & $\begin{array}{l}\text { 1) Easy Speak, 2) Step Ahead, 3) Batam Skills Development Center } \\
\text { (BSDC), 3) Credible College }\end{array}$ \\
\hline 3. & Pelatihan kru kapal pesiar & Captain's Club \\
\hline 4. & Komputer & Credible College \\
\hline 5. & Mesin/Elektro & BSDC \\
\hline 6. & Manajemen Bisnis & 1) DHN Training, 2) MP Consulting \\
\hline
\end{tabular}

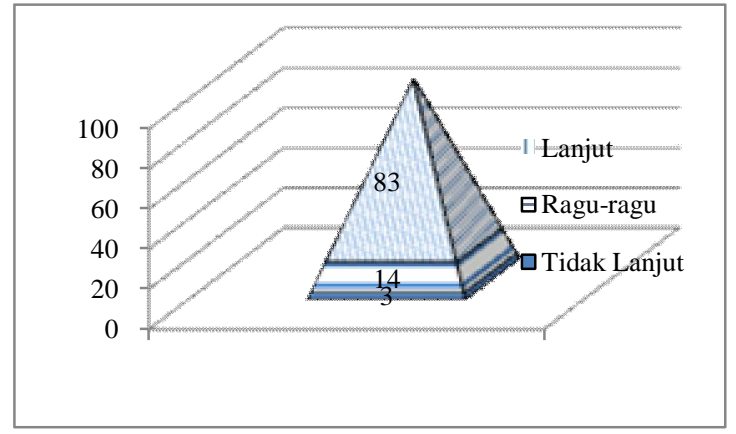

\section{Gambar 3. Minat Lulusan SMA Sederajat} untuk Melanjutkan Pendidikan

Keinginan melanjutkan kuliah ini sangat realistis, bahkan untuk lulusan SMA yang juga berniat bekerja di industri. Hal ini disebabkan oleh luasnya kesempatan bekerja sambil kuliah sementara semua PT di Batam menawarkan kuliah malam. Hasil survei juga menunjukkan bahwa keinginan melanjutkan kuliah pada lulusan SMA bukan semata-mata untuk dapat bekerja, tetapi untuk mendalami ilmu yang diminatinya seperti dapat dilihat pada Gambar 4. Selain dorongan pekerjaan dan minat ilmu, pilihan untuk melanjutkan studi juga didorong oleh orang tua, kemampuan (bakat) akademik, ikut teman, dan sebagainya.

Hal ini menunjukkan bahwa niat calon mahasiswa di Batam tergolong murni, bukan komersial. Tipe mahasiswa di Batam tentu sangat berbeda dengan tipe mahasiswa di Inggris yang cenderung sebaliknya, yaitu mementingkan cari kerja dibandingkan kecintaan terhadap subyek tertentu (Maringe, 2006). Dengan niat mendalami ilmu, perguruan-perguruan tinggi di
Batam dapat membuka program studi yang lebih bervariasi, tidak hanya prodi yang berhubungan erat dengan kebutuhan industri.



Gambar 4. Faktor Pendorong Melanjutkan

Studi

\section{Tekanan Persaingan dari Pelanggan}

Pelanggan adalah pihak yang memberikan tekanan kepada industri untuk meningkatkan kualitas jasa dan menurunkan harga. Pelanggan dibagi menjadi dua, pelanggan internal dan pelanggan eksternal. Priamiani \& Ariani (2005) menyatakan bahwa pelanggan internal adalah staf, sedangkan pelanggan eksternal adalah mahasiswa. Sebenarnya, yang termasuk dalam definisi pelanggan eksternal untuk pendidikan tinggi cukup luas, di antaranya mahasiswa, pemerintah dan industri. Penelitian ini memfokuskan diri pada pelanggan mahasiswa karena kontribusinya yang relatif lebih besar dan lebih stabil daripada kontribusi pelanggan lainnya. 
Saat ini, rasio jumlah lulusan SMA sederajat dibandingkan jumlah PT di tingkat nasional adalah 207:1, di Kepri adalah 435:1, sedangkan di Batam, rasionya 142:1. Semakin kecil rasio di atas, berarti semakin besar kompetisi yang harus dihadapi PT untuk menarik calon mahasiswa. Dengan rendahnya rasio jumlah lulusan SMA sederajat dibandingkan jumlah PT di Batam berarti PT di Batam harus memperebutkan calon mahasiswa yang jumlahnya lebih sedikit daripada PT di luar Batam.

Berdasarkan data dari Dinas Pendidikan Provinsi Kepulauan Riau, pada tahun 2013, sejumlah 99,68 persen siswa lulus Ujian Nasional, artinya, terdapat 16.539 orang yang siap melanjutkan pendidikan tinggi dan atau bekerja.

Tabel 2. Potensi Calon Mahasiswa dari

Lulusan SMA Sederajat

\begin{tabular}{ccc}
\hline Tahun & $\begin{array}{c}\text { Kelulusan } \\
\text { SMA (\%) }\end{array}$ & $\begin{array}{c}\text { Jumlah lulusan } \\
\text { (orang) }\end{array}$ \\
\hline 2013 & 99,68 & 16.539 \\
2012 & 99,04 & 15.101 \\
2011 & 99,50 & 13.796 \\
2010 & 98,36 & 13.565 \\
\hline
\end{tabular}

Tabel 2 di atas mengindikasikan adanya kecenderungan kenaikan jumlah lulusan sejak tahun 2010 hingga tahun 2013. Kecenderungan kenaikan ini diprediksikan akan tetap terjadi di tahun-tahun berikutnya mengingat pertambahan jumlah penduduk. Tabel juga memperlihatkan bahwa persentase kelulusan siswa SMA sederajat tampak berfluktuasi setiap tahun, namun kisarannya antara 98 hingga 99,7 persen dianggap cukup masuk akal. Tingginya persentase kelulusan dan tren positif dari jumlah lulusan SMA sederajat di Kepri dapat meringankan tingkat persaingan pendidikan tinggi di Batam.

Berdasarkan survei terhadap 1970 responden ditemukan bahwa persentase lulusan SMA sederajat yang berminat melanjutkan pendidikan cukup tinggi, yaitu 83 persen, sisanya memilih untuk bekerja atau menikah dan sebagainya.

Selanjutnya, potensi calon mahasiswa Polibatam juga dapat diestimasi dari persentase calon mahasiswa yang berminat melanjutkan kuliah di Politeknik yaitu sebesar 17\%. Grafik di bawah ini menunjukkan minat mayoritas calon mahasiswa untuk melanjutkan ke sebuah universitas.



\section{Gambar 5. Jenis Pendidikan Tinggi yang} Diminati Lulusan SMA Sederajat

Selain potensi kuantitas, penelitian ini juga menelusuri minat mahasiswa terhadap jenjang pendidikan yang ditawarkan.

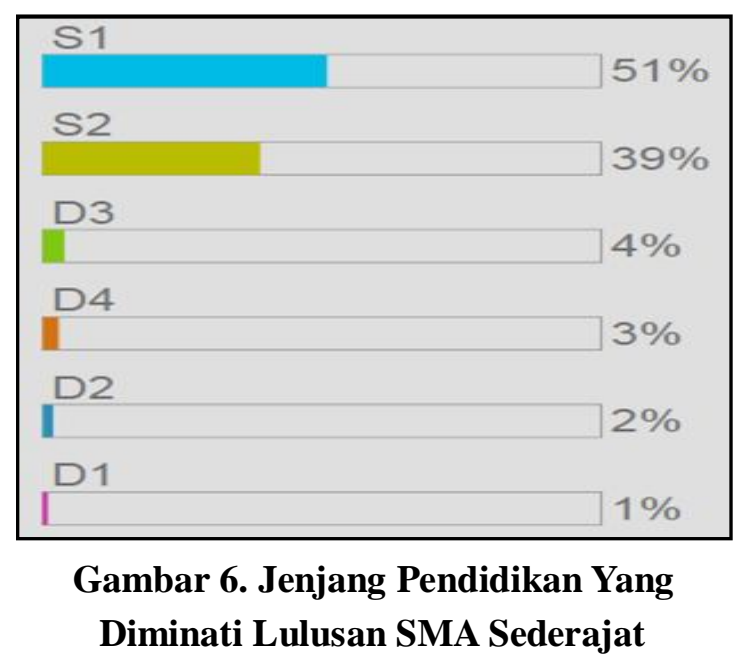

Berdasarkan kedua gambar diatas (Gambar 5 dan Gambar 6) terlihat bahwa minat lulusan SMA sederajat terhadap Politeknik dan jenjang pendidikan yang ditawarkan Politeknik (jenjang diploma) tergolong sangat rendah. Fakta ini tentu tidak menguntungkan bagi Polibatam di tengah persaingan pendidikan tinggi di Batam. Adapun jurusan-jurusan yang diminati dibagi menjadi jurusan sosial dan sains. 
Tabel 3. Jurusan Sosial yang Diminati Lulusan SMA Sederajat

\begin{tabular}{lll}
\hline Jurusan Sosial & $\begin{array}{l}\text { Jumlah } \\
\text { Peminat }\end{array}$ & $\%$ \\
\hline Manajemen & 464 & 13 \\
Bahasa Inggris & 319 & 9 \\
Hukum & 295 & 8 \\
Keuangan dan Perbankan & 278 & 8 \\
Akuntansi & 263 & 8 \\
Psikologi & 227 & 7 \\
AdministrasiBisnis & 25 & 6 \\
Perpajakan & 198 & 6 \\
Ekonomi & 180 & 5 \\
Sekretaris & 169 & 5 \\
Kependidikan & 155 & 4 \\
Perhotelan & 149 & 4 \\
Pemasaran/Marketing & 132 & 4 \\
Sosial Politik & 122 & 4 \\
Akuntansi Manajerial & 120 & 3 \\
BahasaAsing lain & 75 & 2 \\
BahasaMandarin & 70 & 2 \\
Lainnya.... & 35 & 1 \\
Total & 3476 & 100 \\
\hline
\end{tabular}

Tabel 3 dan 4 memperlihatkan bahwa peminat jurusan sosial lebih banyak daripada peminat jurusan sains/teknik sehingga tidak heran jika usulan PT yang masuk Dikti masih didominasi jurusan sosial (Napitupulu, 2012). Sementara itu, empat jurusan yang paling diminati di bidang sosial tidak disediakan di Polibatam. Meskipun demikian, Polibatam menawarkan variasi jurusan sains/teknik yang lebih komplit daripada variasi jurusan sosial.

Selanjutnya, untuk lebih memahami calon pelanggan, penelitian ini berusaha mengidentifikasi tidak hanya potensi kuantitas, namun juga minat dan perilaku calon pelanggan. Untuk itu, dilakukan uji faktor utama dalam pemilihan PT menurut persepsi lulusan SMA sederajat.

- Kualitas dosen, dipilih sesuai dengan penelitian Mardiyono (2006), Priamiani \&Ariani (2005), dan Rifandi (2013).

- Bauran pemasaran jasa (Kotler, 1994).

- Product (jasa) atau jurusan yang ditawarkan (Maringe, 2006).
Tabel 4. Jurusan Sains yang Diminati Lulusan SMA Sederajat

\begin{tabular}{lrr}
\hline Jurusan Sains & \multicolumn{2}{l}{$\begin{array}{l}\text { Jumlah } \\
\text { Peminat }\end{array}$} \\
\hline Teknik/Ilmu Komputer & 361 & 13 \\
Informatika/SI & 340 & 12 \\
Multi media dan Jaringan & 301 & 11 \\
Kedokteran & 234 & 8 \\
Arsitektur & 185 & 7 \\
Teknik Mesin & 159 & 6 \\
Kebidanan & 152 & 5 \\
Penerbangan & 127 & 5 \\
Perkapalan & 124 & 4 \\
Matematika & 110 & 4 \\
Teknik Elekronika & 105 & 4 \\
Keperawatan & 102 & 4 \\
Teknik Sipil & 92 & 3 \\
TeknikIndustri & 79 & 3 \\
MesinProduksi & 61 & 2 \\
Fisika & 48 & 2 \\
Lainnya....... & 43 & 2 \\
MesinEksploitasi Migas & 42 & 1 \\
Mekatronika & 40 & 1 \\
Pertanian & 39 & 1 \\
MikroElektronik & 26 & 1 \\
Pemetaan Kelautan & 25 & 1 \\
Teknik Instrumentasi & 15 & 1 \\
Total & 2810 & 100 \\
\hline
\end{tabular}

- Priceatau biaya kuliah (Maringe, 2006);

- Place/Delivery atau lokasi kampus.

- Promotion, sebagai bagian dari university marketing(Nicolae \& Marinescu, 2010), (Brendan, et al., 2003), terdiri atas: prestise/reputasi dan popularitas kampus di antara teman-teman.

- Physical evidence (Rifandi, 2013) atau infrastruktur pendukung.

- Process atau kualitas PT, sesuai penelitian Rosana (2009:296), Priamiani \& Ariani (2005:178), Rifandi (2013), Rachel, et al.(2013), Beach \& Burns (1995): tingkat akreditasi kampus, status "Negeri' PT, dan sistem perkuliahan;

- People/participants, di antaranya: reputasi alumni dan kemauan orang tua. 
Berdasarkan variabel-variabel di atas, hasil survei ditunjukkan pada Gambar 7.



Gambar 7. Variabel Utama yang Mempengaruhi Pemilihan Kampus

Pada grafik di atas terlihat bahwa faktor biaya kuliah dianggap sebagai faktor yang kurang dominan dalam pemilihan PT. Artinya, calon pelanggan kurang sensitif terhadap perubahan biaya kuliah. Salah satu penyebab ketidaksensitifan ini adalah tingginya tingkat penghasilan masyarakat (BPS, 2014). Hal ini tentu menguntungkan bagi pendidikan tinggi di Batam, sebab pendidikan tinggi lokal dapat menerapkan biaya kuliah yang relatif fleksibel.

\section{Tekanan Persaingan dari Pemasok}

Polibatam, utamanya bagian pengadaan, menjaga hubungan baik dengan para pemasok dan telah menerapkan standar mutu ISO 9001: 2008 dalam sistemnya. Jumlah pemasok sangat banyak; mereka hasil seleksi dari proses pengadaan barang dan jasa yang sesuai dengan Peraturan Presiden Nomor 70 Tahun 2012, baik secara swakelola, penunjukan langsung, ataupun lelang. Daftar pemasok berubah-ubah setiap tahunnya karena proses lelang yang terbuka dan daftar hitam yang terbarukan. Meskipun daftar pemasok berubah-ubah, Polibatam tidak kesulitan mencari pengganti sebab sebagian besar barang dan jasa yang dibutuhkan tersedia di pasar bebas. Akibat aturan pemerintah mengenai pengadaan barang dan jasa, biaya berpindah atau tidak berpindah antar pemasok relatif tetap. Dengan demikian, tekanan persaingan dari pemasok cenderung lemah.

\section{Tekanan Persaingan dari Kompetitor}

Smith (2000) juga menekankan pentingnya peran kompetitor, tidak hanya sebagai pesaing, namun juga sebagai benchmark agar organisasi jasa dapat meningkatkan kualitas dan daya saingnya. Analisis tekanan persaingan dari kompetitor dilakukan dengan menggunakan variabel-variabel yang paling penting menurut persepsi calon pelanggan. Gambar di atas menunjukkan komponen terpenting bagi pelanggan dalam memilih kampus adalah kualitas dosen kemudian diikuti dengan tingkat akreditasi kampus. Hasil penelitian ini diharapkan dapat menjadi masukan bagi pendidikan tinggi di Batam agar dapat memformulasikan strategi yang tepat dan cocok dengan harapan pelanggan yang menganggap kualitas pendidik dan akreditasi sebagai variabel utama dari sebuah PT.

Berdasarkan kedua komponen terpenting di atas, digabungkan dengan survei identifikasi kompetitor Polibatam, selanjutnya peneliti menyusun peta posisi (positioning) pendidikan tinggi seperti yang tampak pada Gambar 8 .

Disadari atau tidak, pendidikan tinggi di Batam telah memetakan posisinya masing- masing sehingga telah terbentuk impresi/kesan pada benak pelanggan (Ries \& Trout, 1981) seperti pada gambar di atas. Polibatam berada pada posisi lemah atau tertinggal jauh dari beberapa kampus besar lainnya yang posisinya sangat berdekatan. Dengan posisinya yang berdekatan pada peta persepsi lulusan SMA sederajat, maka Polibatamakan kesulitan memberikan diferensiasi jasa kepada masyarakat. Padahal, posisi yang tepat di pasaran sangat berpengaruh terhadap daya saing organisasi, utamanya daya saing jangka panjang jangka panjang (Porter, 1996). Dengan demikian, tekanan kompetisi yang dirasakan Polibatam akan sangat kuat disebabkan diferensiasi yang kurang jelas. 


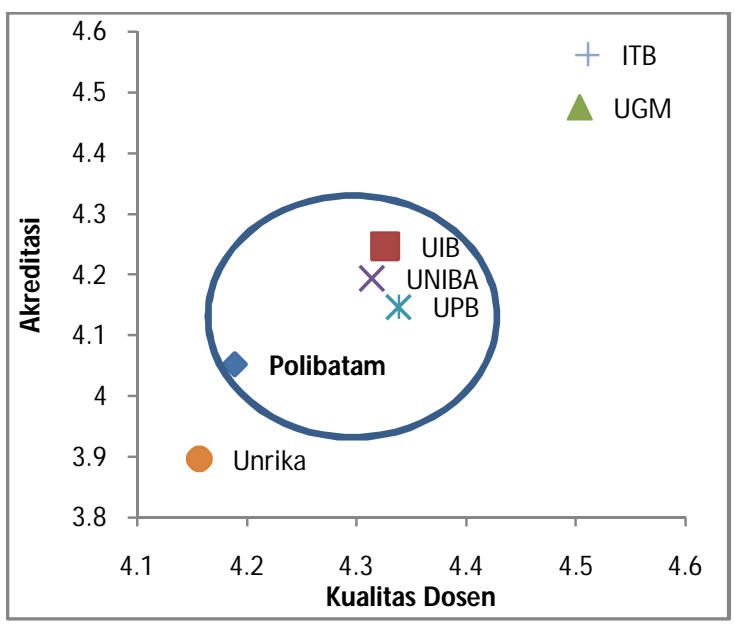

Gambar 8. Peta Posisi Pendidikan Tinggi (Kualitas vs Akreditasi)

Perguruan tinggi-perguruan tinggi yang dianggap kompetitor Polibatam terdiri dari PT lokal dan nasional. Dari 7.564 PT di luar Kepri, ada dua PT yang dipersepsikan kompetitor Polibatam, yaitu UGM dan ITB, keduanya tergolong sangat kuat. Dari 38 PT di Kepri, ada lima PT yang dipersepsikan kompetitor Polibatam, yaitu Universitas Internasional Batam (UIB), Universitas Batam (Uniba), Universitas Putera Batam (UPB), dan Universitas Riau Kepulauan (Unrika). Dengan Unrika, posisi Polibatam terlihat lebih unggul. Namun, jika dibandingkan dengan 3 PT besar lainnya, Polibatam tergolong inferior. Oleh sebab itu, Polibatam perlu mengevaluasi posisinya agar mampu berkompetisi di Batam.

Meskipun grafik di atas dibuat berdasarkan persepsi calon pelanggan, hal itu cukup mencerminkan realitas yang ada. Di Batam, satu-satunya PT yang memunyai prodi terakre- ditasi A hanya UIB sehingga tidak mengejutkan jika masyarakat menempatkan UIB pada bagian teratas dari semua PT lokal. Mengenai kualitas dosen, persepsi calon pelanggan sesuai dengan fakta seperti yang dapat dilihat pada Tabel 5 .

Semakin banyak jumlah mahasiswa yang ditangani oleh satu orang dosen, semakin menurun kualitas pengajaran dosen tersebut. Berdasarkan data di atas, kualitas pengajaran dosen Polibatam dipersepsikan rendah karena rata-rata jumlah mahasiswa yang harus ditangani oleh satu orang pengajar di Polibatam sangat banyak yaitu $1: 41,1$.

Guerrieri \& Meliciani (2004:7) menyebutkan bahwa daya saing organisasi dapat direfleksikan melalui persentase pangsa pasar yang dikuasai organisasi (market share). Berdasarkan data Dikti (2014), market share Polibatam tak lebih dari $10 \%$.

Jika dibandingkan dengan PT lokal sebagai kompetitornya, Polibatam memiliki market share yang lebih kecil. Dengan demikian, tekanan persaingan dari kompetitor lokal tergolong kuat.

Secara umum, pelanggan mudah berpindah antarkampus sebab PT di Batam memberikan skema transfer atau pindahan. Namun, biaya untuk pindah (switching cost) ke kampus kompetitor lebih tinggi daripada biaya untuk tetap melanjutkan kuliah di Polibatam. Hal ini diperkuat dengan fakta dari Gambar 7 yang menunjukkan bahwa faktor biaya kuliah dianggap sebagai faktor yang kurang dominan dalam pemilihan PT.

Tabel 5. Perbandingan Berbagai Parameter Pendidikan Tinggi di Batam

\begin{tabular}{lllllll}
\hline Kampus & $\begin{array}{l}\text { Rasio Dosen: } \\
\text { Mahasiswa }\end{array}$ & $\begin{array}{l}\text { Jumlah } \\
\text { Mahasiswa }\end{array}$ & $\begin{array}{l}\text { Market } \\
\text { Share }\end{array}$ & Uang Pangkal & $\begin{array}{l}\text { Biaya per } \\
\text { semester }\end{array}$ & $\begin{array}{l}\text { Jumlah } \\
\text { Prodi }\end{array}$ \\
\hline UPB & $1: 35,2$ & 6.701 & $18 \%$ & $2.300 .000-$ & $2.600 .000-$ & 13 \\
& & & & 8.000 .000 & 7.000 .000 & 19 \\
Uniba & $1: 22,7$ & 10.477 & $28 \%$ & 11.650 .000 & 3.000 .000 & 19 \\
Unrika & $1: 27,0$ & 9.979 & $26 \%$ & 3.500 .000 & $1.500 .000-$ & 15 \\
& & & & & 3.000 .000 & 9 \\
UIB & $1: 19,9$ & 7.043 & $19 \%$ & 12.700 .000 & $2.600 .000^{*}$ & 8 \\
Polibatam & $1: 41,1$ & 3.781 & $10 \%$ & 0 & $2.250 .000-$ & 3.750 .000 \\
\end{tabular}

* Belum termasuk biaya praktikum 
Loyalitas pelanggan ditinjau dari aspek biaya kuliah cenderung kuat. Akan tetapi, persentase drop-out Polibatam yang mencapai angka 30 menunjukkan bahwa loyalitas pelanggan tidak hanya dipicu oleh biaya kuliah, namun juga sistem perkuliahan, variasi jurusan.

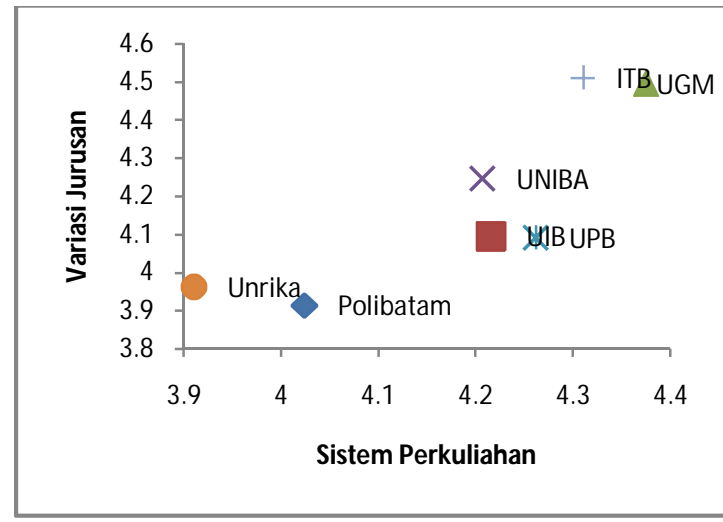

\section{Gambar 9. Peta Posisi Pendidikan Tinggi} (Sistem Perkuliahan vs Variasi Jurusan)

Dibandingkan dengan kompetitornya, Polibatam menawarkan variasi jurusan yang paling terbatas (lihat Tabel 5) sehingga sulit bersaing dengan kampus lainnya.

Tekanan persaingan dari kompetitor dapat berkurang jika kompetitor menutup kampusnya. Kasus penutupan PT bukan hal yang baru. Muhammad Nuh (Suara Merdeka, 2011) mengatakan bahwa hampir sepertiga dari 3.017 PTS (PTS) di Indonesia tutup karena jurusannya kurang diminati dan kalah bersaing dengan perguruan tinggi negeri. Persoalannya bukan masalah kebijakan, tetapi biaya operasional pendidikan. Oleh sebab itu, untuk bersaing, PTS harus kreatif dan mampu beradaptasi dengan kebutuhan masyarakat.

Ketika perguruan tinggi ditutup, biaya yang perlu dikeluarkan manajemen sebenarnya cukup besar, di antaranya adalah biaya pesangon dosen tetap dan staf, pengembalian biaya kuliah yang sudah dibayar oleh mahasiswa, serta biaya penalti oleh pemilik bangunan jika perguruan tinggi tersebut menyewa bangunan. Semakin besar biaya yang dikeluarkan PT untuk meninggalkan dunia pendidikan, semakin besar tekanan kompetisi dari PT tersebut terhadap dunia pendidikan.

\section{Pembahasan}

Ancaman persaingan dari pendatang baru termasuk kuat. Desakan persaingan dari pendatang baru utamanya disebabkan biaya pendirian PT yang relatif terjangkau dan mekanisme pendirian PT yang transparan dan cepat; keduanya menyebabkan banyaknya pendirian PT baru lokal. Selain itu, standarisasi yang ditetapkan Dikti menyebabkan pendatang baru mempunyai panduan yang jelas untuk meningkatkan kualitasnya dan berkompetisi dengan PT lama.

Ancaman persaingan dari penyedia jasa subsititusi dikategorikan moderat-kuat. Tekanan persaingan pendidikan tinggi lokal utamanya dihasilkan oleh pendidikan tinggi luar daerah. Penyedia jasa pendidikan non formal dan sertifikasi juga memberikan tekanan persaingan, namun tidak sekuat tekanan PT dari luar daerah.

Tekanan persaingan dari perspektif pelanggan diklasifikasikan moderat. Polibatam diuntungkan dengan fakta jumlah calon mahasiswa/lulusan SMA sederajat lokal yang terus meningkat serta daya beli yang tinggi dari masyarakat Batam. Di sisi lain, Polibatam dirugikan oleh fakta bahwa minat calon mahasiswa terhadap Politeknik, jenjang diploma, dan jurusan yang ditawarkan Polibatam sangat rendah.

Dengan menggunakan analisis peta posisi pendidikan tinggi, terlihat bahwa diferensiasi yang dilakukan oleh Polibatam kurang jelas, sehingga jasa yang ditawarkannya dipersepsikan serupa dengan kompetitornya. Polibatam juga dipersepsikan kurang unggul dibandingkan kompetitornya yang terdiri dari kompetitor lokal dan kompetitor non lokal, sehingga, tekanan persaingan dari kompetitor termasuk kuat.

Dari Gambar 10 terlihat bahwa hanya tekanan persaingan dari pemasok yang cenderung lemah; tekanan persaingan dari unsur-unsur lainnya yaitu pelanggan, kompetitor, penyedia jasa substitusi, dan pendatang baru cenderung moderat - kuat. Analisis lima kekuatan Porter untuk menggambarkan persaingan pendidikan di Batam dapat dilihat pada Gambar 10. 


\begin{tabular}{|c|c|c|}
\hline $\begin{array}{l}\text { Ancaman Pendatang Baru } \\
\text { - Biaya pendirian perguruan tinggi } \\
\text { relatif tidak mahal } \\
\text { - Spesialisasi dibutuhkan, tetapi } \\
\text { training tersedia } \\
\text { - Economies of scale lemah } \\
\text { - Efisiensi biaya karena telah } \\
\text { memasuki dunia pendidikan cukup } \\
\text { lama lemah } \\
\text { - Proteksi teknologi tidak ada } \\
\text { - Hambatan bagi pendatang baru } \\
\text { lemah, namun mulai meningkat karena } \\
\text { moratorium dari Dikti } \\
{ }^{\star} \text { Total: Ancaman Pendatang Baru } \\
\text { terhadap Persaingan Kuat (---) }\end{array}$ & $\begin{array}{c}\text { An- } \\
\text { cam- } \\
\text { an } \\
\text { pen- } \\
\text { da- } \\
\text { tang }\end{array}$ & $\begin{array}{l}\text { Kekuatan Kompetitor } \\
\text { - Kompetitor lokal relatif banyak } \\
\text { - Kompetitor luar Kepri kuat } \\
\text { - Jasa yang ditawarkan relatif } \\
\text { serupa } \\
\text { - Pelanggan mudah berpindah } \\
\text { kampus } \\
\text { - Loyalitas pelanggan moderat } \\
\text { - Biaya penutupan kampus } \\
\text { moderat } \\
\text { *Total: Kekuatan Kompetitor } \\
\text { terhadap Persaingan Kuat (---) }\end{array}$ \\
\hline Kekuatan Tawar Pemasok & & Kekuatan Tawar Pembeli \\
\hline $\begin{array}{l}\text { Kekuatan Tawar Pemasok } \\
\text { - Jumlah pemasok banyak } \\
\text { - Produk dan jasa serupa } \\
\text { - Mudah dan murah berpindah antar pemasok } \\
\text { `Total: Kekuatan Pemasok terhadap } \\
\text { persaingan: Lemah (0) } \\
\text { Ancaman Jasa Substitusi } \\
\text { - Kuatnya daya tarik pendidikan tinggi dari } \\
\text { luar daerah } \\
\text { - Moderat daya tarik jasa substitusi } \\
\text { pendidikan non formal dan sertifikasi } \\
\text { - Moderat daya tarik jasa substitusi karir - } \\
\text { pilihan bekerja } \\
\text { *Total: Ancaman Jasa Substitusi terhadap } \\
\text { persaingan: Moderat - Kuat (--) }\end{array}$ & \begin{tabular}{|c} 
Ja- \\
sa \\
Sub- \\
sti- \\
tu- \\
si
\end{tabular} & $\begin{array}{l}\text { Kekuatan Tawar Pembeli } \\
\text { - Rasio jumlah lulusan SMA sederajat } \\
\text { dibandingkan jumlah perguruan tinggi } \\
\text { di Batam lebih rendah daripada } \\
\text { nasional, jumlah lulusan SMA terbatas } \\
\text { - Diferensiasi menurut persepsi } \\
\text { pembeli kurang jelas } \\
\text { - Mudah berpindah antar perguruan } \\
\text { tinggi } \\
\text { - Kurang sensitif terhadap biaya kuliah } \\
\text { - Daya beli tinggi } \\
\text { *Total: Kekuatan Pembeli terhadap } \\
\text { persaingan: Moderat (-) }\end{array}$ \\
\hline
\end{tabular}

\section{Gambar 10. Analisis Persaingan Pendidikan Tinggi di Batam Menggunakan Lima Kekuatan Porter}

\section{PENUTUP}

Berdasarkan pembahasan di atas, dapat disimpulkan bahwa ancaman/tekanan persaingan dari pendatang baru dan kompetitor termasuk kuat, sedangkan desakan persaingan dari penyedia jasa substitusi dan pembeli tergolong moderat-kuat. Hanya tekanan dari pemasok yang cenderung lemah-normal terhadap persaingan pendidikan tinggi di kota Batam. Sebagai pendidikan tinggi vokasi yang menjadi tolok ukur dalam penelitian ini, Polibatam diharapkan untuk mereposisi dirinya dalam peta persaingan pendidikan tinggi di Batam agar mampu berkembang.

\section{UCAPAN TERIMA KASIH}

Penulis berterima kasih atas bantuan dana Program Penelitian Unggulan Terapan Polibatam tahun anggaran 2013. Secara khusus, tim peneliti berterima kasih kepada Bapak Hendra Gunawan SE, M.Sc. 


\section{DAFTAR PUSTAKA}

Badan Pusat Statistik Kepri. 2012. Kepri dalam Angka. http://kepri.bps.go.id/ Diunduh 20 Juli, 2013.

Badan Pusat Statistika. BRS, 2 Januari 2014. http://www.bps.go.id/brs_file/sbh_02jan 14.pdf. Diunduh27 Maret 2014.

Beach, L. R., \& Burns, L. R. 1995. "The Service Quality Improvement Strategy: Identifying Priorities for Change". International Journal of Service Industry Management. 6(5), hlm. 5-15.

Brendan, J. G., Kim, S. F., \& Violeta, A. L. 2003. "Branding Universities in Asian Markets". Journal of Product \& Brand Management, 12(2), hlm. 108-120.

Dinas Pendidikan Provinsi Kepulauan Riau. 2013. Arsip. http://disdik-kepri.com/download-arsip.Diunduh31 Maret 2014.

Direktorat Jenderal Pendidikan Tinggi. 2012. Kopertis XII: SE No. 393/E/T/2012. http://

www.kopertis 12.or.id/wp-content/upload s/2012/06/Edaran-tentang-Tata-cara-pen dirian-dan-perubahan-bentuk-PT.pdf. (diunduh 17 Maret2014).

Dirjen Pendidikan Tinggi. 2014. http://forlap. dikti.go.id/. (diunduh 17 Maret2014).

Guerrieri, P., \& Meliciani, V. 2004. "International Competitiveness in Producer Services", dalam http://ssrn.com, hlm. 7.

Inhu Makmur Raya. 2012. Fokus. http://www.inhusatu.com/index.php/berita/detail/211 -mendirikan-universitas-minimal-2-tahun\#.UybXU4XSe01. Diunduh 17 Maret 2014.

Kotler, P. 1994. Marketing Management: Analysis, Planning, and Control. New York: Prentice-Hall.
Mardiyono, S. 2006. "Praktik Pengalaman Lapangan Terpadu Dalam Peningkatan Kualitas Calon Guru". Cakrawala Pendidikan, 1, hlm. 57-72.

Maringe, F. 2006. "University and Course Choice: Implications for Positioning, Recruitment and Marketing". International Journal of Educational Management, 20 (6), hlm.466 - 479.

Napitupulu, E. L. 2012. News: Kompas.com. http://edukasi.kompas.com. Diunduh 15 Maret2014.

Nicolae, M., \& Marinescu, R. 2010. "University Marketing - Innovative Communication for Effective Inter/National Survival". Journal for Communication Studies, ESSACHESS, 3(1), 5, hlm. 118-138.

Porter, M. 1990. "The Competitive Advantage of Nations". Harvard Business Review, hlm. 74-90.

Porter, M. 1996. "What is strategy?". Harvard Business Review, November - December, 61-78.

Priamiani, C. N., \& Ariani, W. 2005. "Total Quality Management dan Service Quality dalam Organisasi Pendidikan Tinggi”. Cakrawala Pendidikan, 2, hlm. 178-203.

Rachel, W. Y., Andy, C. Y., Edwin, C., \& Peter, K. L. 2013. "Market Competitiveness and Quality Performance in High-Contact Service Industries". Industrial Management \& Data Systems. 113(4), hlm. 573-588.

Ries, A., \& Trout, J. 1981. Positioning, the Battle For Your Mind. New York: Warner Books - McGraw-Hill Inc.

Rifandi, A. 2013. "Mutu Pembelajaran dan Kompetensi Lulusan Diploma III Politeknik". Cakrawala Pendidikan, hlm. 125-138. 
Rosana, D. 2009. "Pengembangan Budaya Kualitas Melalui Penerapan ISO 9001: 2000 di Universitas Negeri Yogyakarta", dalamCakrawala Pendidikan, 3(3), hlm. 296-307.

Rurit, B. 2008. Tempo Interaktif. http://tempo.co.id/hg/nusa/jawamadura/2008/08/05/br k, 20080805-129779, id.html. Diunduh 17 Maret 2014.

Smith, A. M. 2000. "Using Consumer Benchmarking Criteria to Improve Service Sector Competitiveness". Benchmarking: An International Journal, 7(5), hlm. 373-388.
Suara Merdeka. 2011. Pendidikan. http:// www.suaramerdeka.com/v2/index.php/re ad/cetak/ 2011/03/25/141198/Tak-AdaPTS-Jateng-Gulung-Tikar. Diunduh 17 Maret 2014.

Widiyoko, S. 2012. Ekonomi Marketing. http://ekonomi.kompasiana.com/marketing/2 012/ 03/13/strategi-marketing-perguruan-tinggi-442099.html. Diunduh $17 \mathrm{Ma}-$ ret 2014. 